\title{
Pemberdayaan masyarakat melalui pelatihan pembuatan ecobrick sebagai upaya mengurangi sampah plastik di Kecamatan Bunga Raya
}

\section{Muhammad Fauzi ${ }^{\star 1}$, Eni Sumiarsih', Adriman1, Rusliadi², \& Ika Fitria Hasibuan $^{3}$}

1 Jurusan Manajemen Sumberdaya Perairan, Fakultas Perikanan dan Kelautan, Universitas Riau, Indonesia

2 Jurusan Manajemen Budidaya Perairan, Fakultas Perikanan dan Kelautan, Universitas Riau, Indonesia

${ }^{3}$ Sekolah Tinggi Pariwisata Riau, Indonesia

\section{*m.fauzi@lecturer.unri.ac.id}

\begin{abstract}
Plastics are the synthesis of polymerization of different types of monomers. Almost all kinds of plastic will drift or float inside the water body. It will cause the plastic to be torn apart and damaged by the sunlight, oxidation and abrasion of mechanically forming plastic particles. Ecobrick is one way of handling plastic waste by packing clean and dry plastic into plastic bottles. Community empowerment to process plastic waste into something useful in the long term is one of the keys to the success of the plastic waste recycling program. This activity will provide benefits for community service participants, members who implement counselling, higher education and government. The target audience in these community service activities is the village community Bunga Raya, Siak regency. Results of public service activities that have been implemented by the community have been able to make seats from Ecobrick. In society, it is expected not only to make seats from Ecobrick but also to create other creations. So it can be used as a new business opportunity for the target community.
\end{abstract}

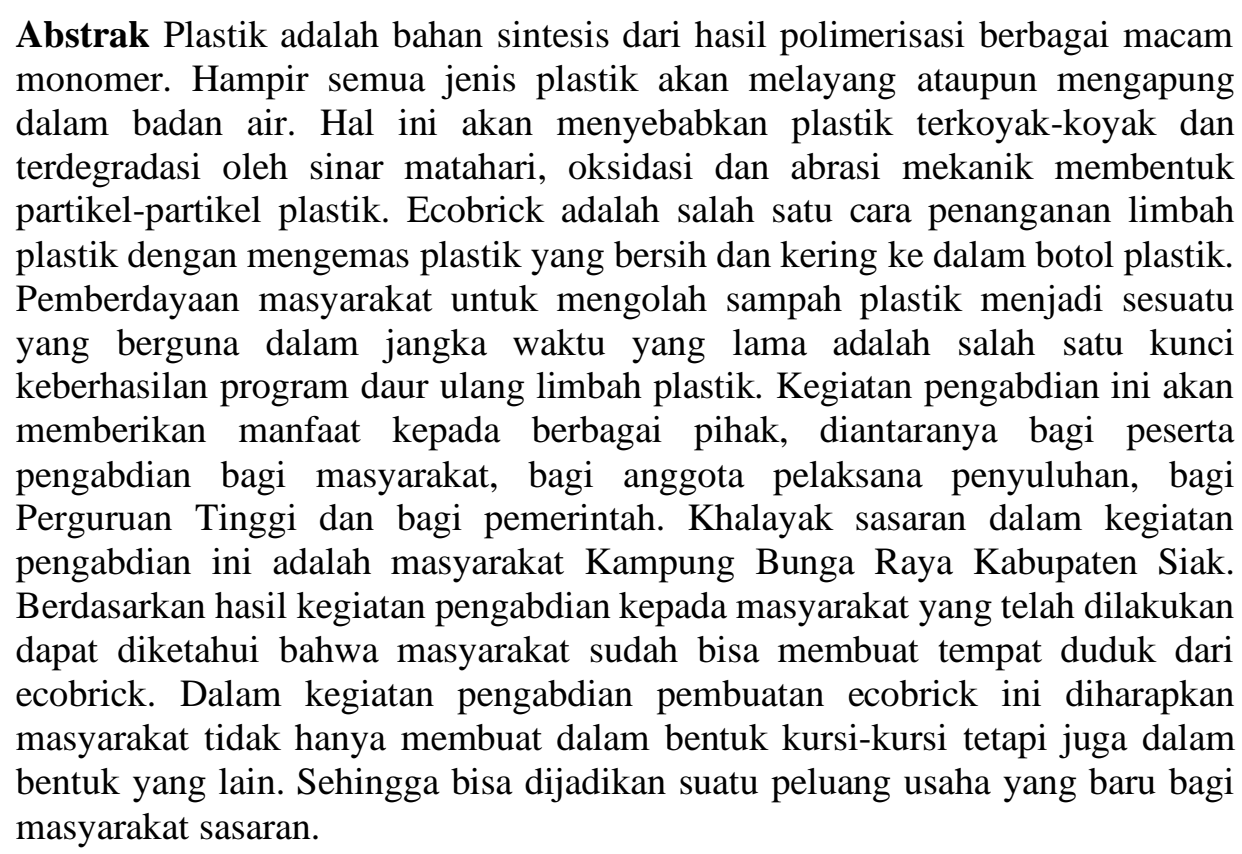

\section{ठ OPEN ACCESS}

Citation: Fauzi, M., Sumiarsih, E., Adriman., Rusliadi, \& Hasibuan, I.F. (2020) Pemberdayaan masyarakat melalui pelatihan pembuatan ecobrick sebagai upaya mengurangi sampah plastik di Kecamatan Bunga Raya. Riau Journal of Empowerment, 3(2), 87-96. https://doi.org/10.31258/raje.3.2.87-96

Paper type: Community service

Received: 2019-11-16 Revised: 2020-07-19 Accepted: 2020-07-20

Language: Bahasa Indonesia (id)

Funding: Universitas Riau

ISSN 2623-1549 (online), 2654-4520 (print)

(c) 2020 Muhammad Fauzi et al. Author(s) retain the copyright of article published in this journal, with first publication rights granted to Riau Journal of Empowerment. The article is licenced under Creative Commons Attribution 4.0

International License. This license permits unrestricted use, distribution, and reproduction in any medium, provided the original author and source are credited. 
Keywords: business opportunity; crafts; pollution; ecobrick; environment; Siak

\section{PENDAHULUAN}

Permasalahan lingkungan yang telah menjadi isu global (mendunia), setelah hampir semua elemen masyarakat menyadari akan bahaya yang ditimbulkan dari kerusakan lingkungan. Salah satu penyebab kerusakan lingkungan adalah pencemaran lingkungan yang disebabkan oleh menumpuknya limbah yang dihasilkan oleh manusia. Bermacam limbah yang dihasilkan oleh aktivitas manusia setiap harinya, ada yang berujud padat, cair dan gas. Limbah yang berujud padat disebut dengan sampah. Beragam aktivitas manusia dapat menimbulkan sampah, baik aktivitas industri, pertanian, rumah sakit, maupun aktivitas domestik (rumah tangga).

Plastik adalah bahan sintesis dari hasil polimerisasi (polycondensation) berbagai macam monomer (stirena, vinil klorida buta diene dan akrilonitril) (Mujiarto, 2005). Polimer plastik merupakan material yang sangat stabil sehingga akan tetap berada dalam kondisi utuh sebagai polimer dalam jangka waktu yang lama (Hohenblum et al., 2015). Hampir semua jenis plastik akan melayang ataupun mengapung dalam badan air. Hal ini akan menyebabkan plastik terkoyak-koyak dan terdegradasi oleh sinar matahari (fotodegradasi), oksidasi, dan abrasi mekanik membentuk partikel-partikel plastik (Thompson et al., 2009). Partikel plastik yang berukuran kecil $\leq 5 \mathrm{~mm}$ disebut mikroplastik (Thompson et al., 2004).

Plastik banyak digunakan dalam berbagai macam kebutuhan hidup manusia. Mulai dari bahan pembungkus makanan hingga keperluan bahan otomotif. Plastik merupakan sebuah bahan yang paling populer dan paling banyak digunakan sebagai bahan pembuat komponen otomotif selain bahan logam berupa besi. Permasalahan yang paling utama dari plastik adalah limbah plastik yang tidak bisa terurai secara alami. Memerlukan waktu yang sangat lama untuk membersihkan sampah plastik dari muka bumi. Terlebih lagi karena penggunaan plastik hampir tidak bisa dikendalikan. Plastik juga menjadikan suhu udara menjadi lebih panas dari ke hari, karena sifat polimernya yang tidak berpori (Suminto, 2017).

Mikroplastik yang tersebar di lautan akan mengendap dan terbawa oleh arus ombak sehingga bercampur dengan pasir pantai. Hasil studi yang telah dilakukan menunjukkan bahwa mikroplastik tersebar luas di lautan pada permukaan laut, pantai, maupun dasar laut (Lusher et al., 2013). Hal ini menyebabkan mikroplastik juga ditemukan pada sedimen di seluruh dunia (Claessens et al., 2013). Sampah plastik juga pada umumnya sulit untuk didegradasi dan menyebabkan pencemaran terhadap lingkungan (Andriastuti et al., 2019).

Pada perairan laut distribusi partikel plastik yang berada dekat pantai, seperti kantong plastik dapat menumpuk di sedimen membuat plastik tidak akan mengapung dan tenggelam (Moore et al., 2004). Sampah plastik melalui proses penguraian botol plastik memakan waktu 450-1.000 tahun, sehingga sampah botol plastik dapat menjadi limbah yang sangat berbahaya. Oleh karena itu sudah banyak negara yang mengurangi produksi botol plastik untuk menekan laju pencemaran akibat botol plastik ini. Selain itu berbagai upaya pemanfaatan sampah botol plastik untuk didaur ulang juga terus digaungkan di masyarakat (Adianti \& Ayuningtyas, 2020).

Ecobrick adalah salah satu cara penanganan limbah plastik dengan cara mengemas plastik yang bersih dan kering ke dalam botol plastik hingga kerapatan yang ditentukan. Saat ini produk ecobrick dibentuk menjadi sesuatu yang berguna seperti kursi, meja, hingga pengganti 
batu bata dalam pembuatan rumah (Asih \& Fitriani, 2018; Fauzi et al., 2019). Ecobrick dibuat dengan cara memasukkan plastik yang sudah dibersihkan dan kering ke dalam botol Polietilen Tereftalat (PET) atau botol minum yang biasa ditemui. Dalam pembuatan ecobrick tidak diperlukan keahlian khusus serta bahan yang diperlukan bersumber dari aktivitas masyarakat sehari-hari.

Sejauh ini keterlibatan masyarakat dalam mengurangi pemakaian dan mendaur ulang plastik masih sangat minim. Biasanya plastik dibakar untuk memusnahkannya dari pandangan. Padahal, jika pembakaran plastik tidak sempurna (dibawah $800{ }^{\circ} \mathrm{C}$ ) dapat membentuk dioksin, yaitu senyawa yang dapat memicu kanker, hepatitis, pembengkakan hati dan gangguan sistem saraf (Sirait, 2009).

Tujuan dari program pengabdian masyarakat kali ini adalah untuk memberikan pelatihan dan pendampingan kepada masyarakat di Kampung Bunga Raya Kabupaten Siak Provinsi Riau sebagai upaya penanggulangan sampah plastik menggunakan metode ecobrick. Tujuan jangka panjang dari program ini adalah kemandirian masyarakat dalam bidang ekonomi sebagai peluang usaha baru menjadikan suatu produk yang berdaya jual tinggi.

Ada beberapa permasalahan yang teridentifikasi di lokasi pengabdian, antara lain peningkatan volume sampah seiring meningkatnya jumlah penduduk, adanya variasi dari jenis sampah, pengelolaan sampah masih kurang mendapat penanganan yang optimal sehingga menimbulkan pencemaran limbah plastik, bagaimana memberdayakan masyarakat dalam mencegah terjadinya pencemaran limbah plastik serta bagaimana meningkatkan pengetahuan masyarakat tentang pengelolaan sampah plastik.

\section{METODE}

Metode yang digunakan dalam penyuluhan ini yaitu dengan metode ceramah dan praktek langsung serta dilakukan evaluasi capaian kegiatan dengan menggunakan alat ukur ketercapaian.

\section{Langkah 1. Metode Ceramah (Materi)}

Metode ceramah yang akan di sampaikan oleh tim pengabdian secara bergantian, metode ini dipilih untuk menyampaikan konsep tentang sampah plastik, bahaya pencemaran sampah limbah plastik bagi kehidupan, dan pengelolaan sampah plastik melalui ecobrick. Penggunaan metode ceramah dikombinasikan dengan memanfaatkan laptop dan LCD untuk menayangkan materi PowerPoint yang dilengkapi dengan gambar-gambar.

Pemanfaatan laptop dan LCD untuk membantu peserta pelatihan lebih mudah memahami tentang bahaya pencemaran limbah plastik, mengingat materi relatif banyak dan waktu pelatihan yang terbatas. Setelah metode ceramah dilanjutkan dengan praktek langsung pembuatan ecobrick. Dengan dilakukannya praktek langsung pembuatan ecobrick ini masyarakat diharapkan memiliki keterampilan membuat ecobrick sehingga dapat membuat ecobrick sendiri.

\section{Langkah 2. Praktek Pembuatan Ecobrick}

Setelah mendengarkan materi melalui Praktek Pembuatan Ecobrick pada kegiatan pengabdian ini melibatkan 10 orang mahasiswa Kuliah Kerja Nyata (Kukerta) Universitas Riau tahun 2019 
yang ada di Kampung Bunga Raya. Mahasiswa ini akan membantu Kegiatan Pengabdian ini dalam pendampingan peserta khususnya pada pendampingan pembuatan ecobrick hingga praktek pembuatan berakhir. Pada saat melakukan monitoring mahasiswa Kukerta juga akan ikut mendampingi Tim Pengabdian turun ke lapangan.

\section{Cara Membuat Ecobrick}

Pertama : siapkan berbagai macam plastik baik plastik kresek, kemasan, sedotan, dan lainlain. Pastikan semuanya kering, tidak mengandung air sama sekali.

Kedua : pilih botol plastik (misalnya kemasan air mineral). Akan lebih ideal jika kita membuat ecobrick bersama komunitas dengan bekas botol minuman bermerek sama sehingga jika kita akan memanfaatkan ecobrick tersebut untuk outdoor project (misalnya dibuat bangku taman) akan lebih mudah karena sudah seragam.

Ketiga : siapkan tongkat kecil untuk mendorong plastik ke dalam botol. Pilih tongkat kecil yang paling nyaman, misalnya terbuat dari kayu atau bambu. Ukurannya pun bisa menyesuaikan dengan tinggi botol.

Keempat : pastikan tidak ada logam, kertas, gelas, dan plastik bio-degradable (plastik yang bisa terurai). Keempat macam barang tersebut masih bisa dimanfaatkan untuk keperluan lain.

Kelima : mulailah dengan menambahkan plastik berwarna. Plastik berwarna ini akan memberikan warna yang artistik saat ecobrick 'dibangun'. Tambahkan plastik berwarna sekitar 1-2 cm. Selanjutnya, masukkan plastik sesuka hati.

Keenam : mulailah untuk mendorong plastik-plastik tersebut dengan tongkat kecil. Pastikan benar-benar mampat tetapi jangan terlalu keras karena jika terlalu keras akan merusak botol plastik dan sampah plastik kembali berhamburan.

Ketujuh : timbanglah ecobrick yang telah dibuat. Rata-rata untuk botol $600 \mathrm{ml}$ adalah 200 gram dan untuk botol $1.500 \mathrm{ml}$ adalah 500 gram.

\section{Alat Ukur Ketercapaian}

Alat ukur ketercapaian kegiatan pengabdian kepada masyarakat ini adalah minimal 50\% peserta pelatihan mengalami peningkatan pemahaman mengenai bahaya sampah plastik yang diukur melalui pre-test dan post-test akan diberikan sebelum dan setelah pemberian materi.

\section{HASIL DAN KETERCAPAIAN SASARAN}

Pengabdian masyarakat ini telah selesai dilakukan pada bulan Juli. Pengabdian ini memberikan manfaat bagi masyarakat di Kampung Bunga Raya Kabupaten Siak dari aspek permasalahan sebelum pengabdian ini dilakukan. Kegiatan pembuatan ecobrick merupakan salah satu inovasi yang merupakan produk hasil pemikiran Russel yang telah berhasil mengurangi polusi dari sampah plastik. Pemanfaatan limbah plastik yang digunakan sebagai bahan pembuatan ecobrick. Ecobrick sendiri adalah botol minuman plastik yang dikemas dengan limbah non-organik untuk membuat blok bangunan yang dapat digunakan kembali. Metode Kegiatan pengabdian ini dilakukan dengan 2 langkah yaitu dengan metode ceramah 
yang berupa materi dan praktek langsung pembuatan ecobrick. Tim pengabdian juga melibatkan anak Kukerta Universitas Riau yang berjumlah 10 orang yang sedang melakukan kegiatan Kukerta di daerah Kampung Bunga Raya.

Kegiatan pembuatan ecobrick ini diharapkan mampu untuk memberikan perubahan yang signifikan terhadap lingkungan di Kampung Bunga Raya. Antusias masyarakat dalam kegiatan ini diawali dengan antusias mereka mendengarkan ceramah/materi yang diberikan oleh tim pengabdian. Sebelum memberikan materi peserta mengerjakan pre-test untuk melihat pengetahuan para peserta sebelum diberikan materi, dan setelah kegiatan berlangsung para peserta juga akan di berikan post-test dengan tujuan ingin melihat apakah mereka sudah paham dengan materi yang telah diberikan.

Setelah tahap pemberian materi, masyarakat dibagi menjadi beberapa kelompok. Setelah pembagian kelompok peserta dari perwakilan tiap kelompok mendapat bahan pembuatan ecobrick dari tim pengabdian (Gambar 1). Dalam hal ini mahasiswa Kukerta Universitas Riau membantu pelaksanaan pembuatan ecobrick.

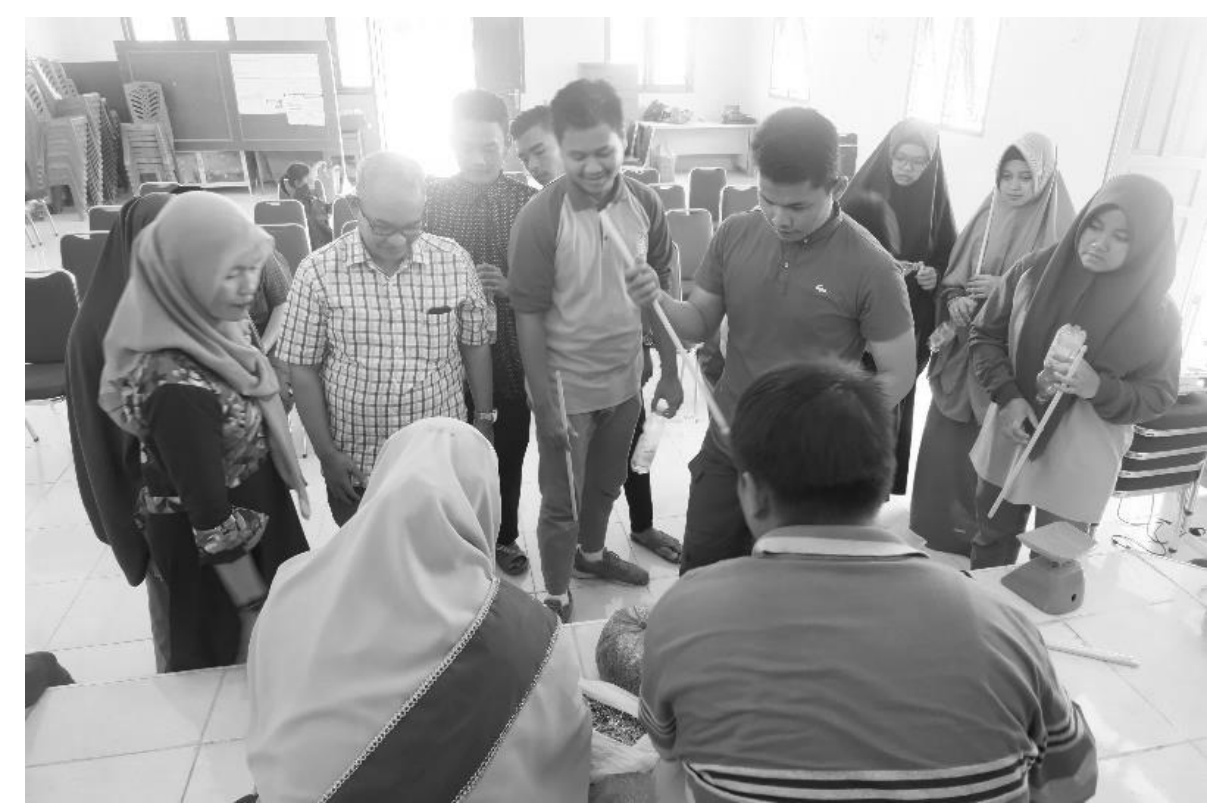

Gambar 1. Pembagian bahan dan alat untuk pembuatan ecobrick

Berdasarkan pengamatan selama kegiatan pengabdian ini diperoleh beberapa hasil positif. Hasil positif tersebut diantaranya (1) para peserta menunjukkan perhatian yang tinggi terhadap ceramah yang disampaikan oleh tim pengabdian, (2) para peserta menunjukkan reaksi positif terhadap ketertarikan dalam membuat ecobrick, (3) para peserta mengikuti prosedur pembuatan produk dan melakukan kerja tim dengan cukup baik, (4) peserta aktif bertanya apabila terdapat prosedur pembuatan yang tidak dimengerti, dan (5) peserta mengerjakan pembuatan produk dengan baik selama 1 jam. Pada tahap evaluasi tim pengabdian memberikan soal untuk me-review kembali tujuan dari pengabdian dengan memberikan soal tentang apa bahaya penggunaan plastik yang berlebihan dan bagaimana cara meminimalisir penggunaan plastik.

Berdasarkan hasil kegiatan pengabdian kepada masyarakat yang telah dilakukan dapat diketahui bahwa masyarakat sudah bisa membuat ecobrick (Gambar 2). Jika dilihat dari kerajinan yang dibuat peserta sudah sesuai dengan apa yang telah diajarkan oleh pemateri. Peserta saat diberi pengarahan juga selalu menyimak dengan baik. Setelah selesai membuat 
ecobrick, ecobrick akan digabungkan menjadi satu dibentuk berbagai macam hal, seperti kursi taman, meja taman, maupun pot bunga. Maka, diharapkan output dari kegiatan ini bisa dimanfaatkan dengan baik oleh masyarakat. Selain itu, dengan ecobrick ini diharapkan masyarakat Kampung Bunga Raya dapat mengelola sampah plastik, sehingga dapat mengurangi pencemaran lingkungan.

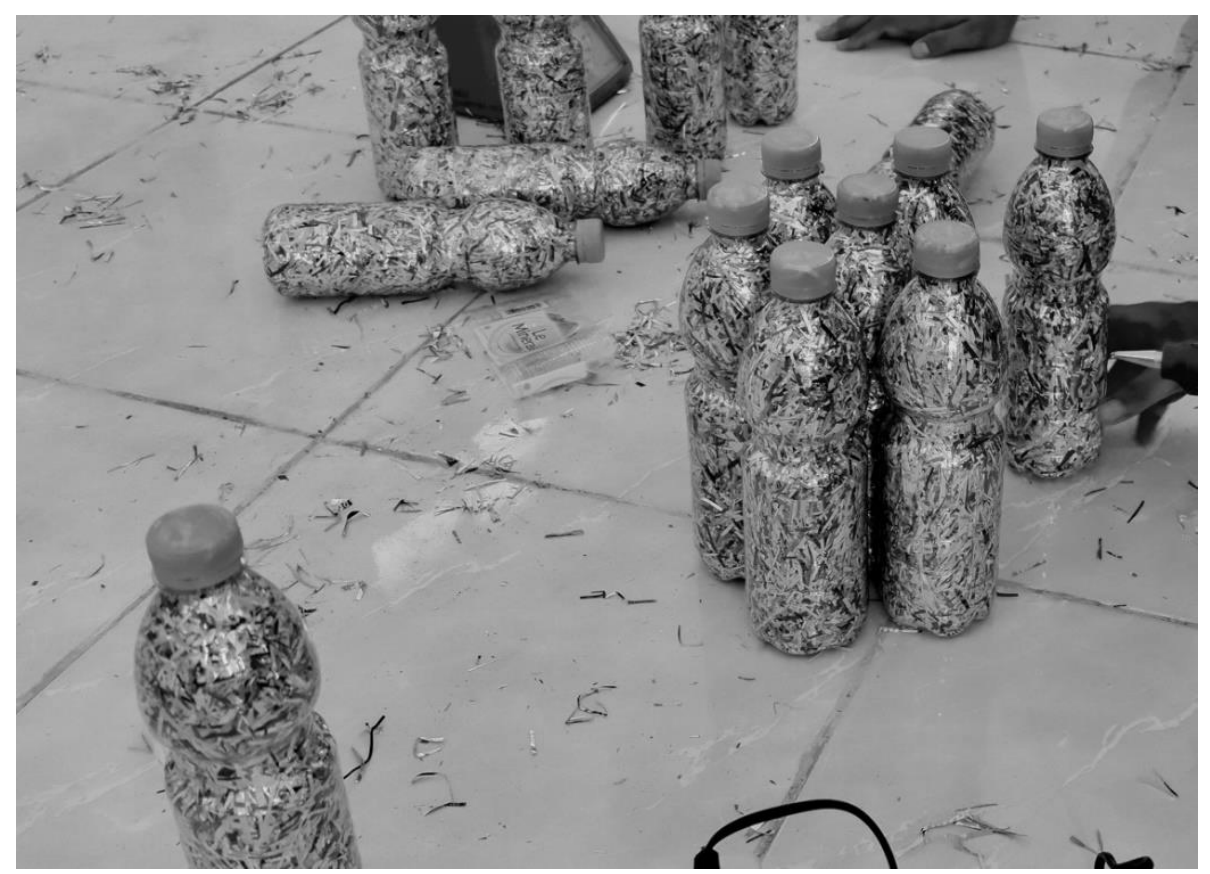

Gambar 2. Hasil pengolahan sampah menjadi ecobrick

Kegiatan pengabdian pembuatan ecobrick ini diharapkan masyarakat tidak hanya membuat dalam bentuk kursi-kursi tetapi juga dalam bentuk yang lain. Sehingga bisa dijadikan suatu peluang usaha yang baru bagi masyarakat sasaran yaitu masyarakat Kampung Bunga Raya. Dalam jangka panjang ecobrick yang terbuat dari botol-botol yang diisi oleh plastik-plastik kecil bisa dijadikan batu bata yang ramah lingkungan. Seperti pada di daerah Jawa, sudah menggunakan Ecobrick untuk membuat rumah sebagai pengganti batu bata, sedangkan di luar negeri hal ini sudah diterapkan seperti di Negara Filipina dan Singapura.

Keunggulan dan kelemahan kegiatan apabila dilihat kesesuaiannya dengan kondisi masyarakat di lokasi kegiatan tidak terlepas dari faktor pendukung dan penghambat. Dalam pelaksanaan kegiatan pengabdian, faktor pendukung tersebut diantaranya (1) antusias masyarakat dalam mengikuti kegiatan pengabdian cukup baik, (2) sikap ingin tahu dan keinginan untuk mencoba hal baru dan bermanfaat dari para peserta pelatihan baik, (3) dukungan dari pemangku desa terhadap kegiatan pengabdian ini baik, (4) bahan-bahan yang digunakan mudah didapatkan, dan (5) proses pembuatan sesuai dengan waktu yang diberikan.

Selain adanya faktor pendukung yang dapat berpengaruh, terdapat juga faktor penghambat. Faktor penghambat kegiatan ini adalah sulitnya mengumpulkan 50 orang peserta. Adapun rerata nilai pre-test dan post-test ditampilkan pada Gambar 3. 


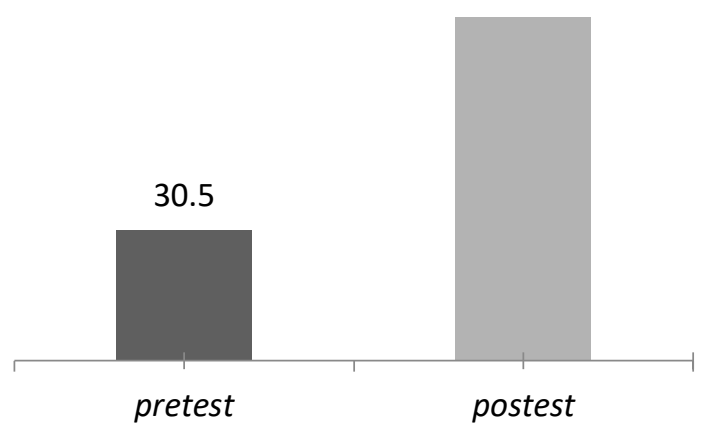

Gambar 3. Rerata nilai pre-test dan post-test pada kegiatan pengabdian

Rerata nilai pre-test dan post-test jauh berbeda, yaitu 30,6 pada pre-test dan 80,5 pada posttest. Kisaran nilai ini menunjukkan bahwa sebelum mengikuti penyuluhan, masyarakat belum mempunyai bekal pengetahuan tentang ecobrick akan tetapi pengetahuan ini meningkat dengan adanya materi yang diberikan. Dengan demikian dapat disimpulkan bahwa kegiatan pengabdian ini memberikan pengaruh positif terhadap pengetahuan peserta sehingga nantinya kampung Bunga Raya dapat menjadi desa percontohan bagi desa lainnya dan akan menjadi desa/kampung yang bersih serta dibukanya usaha kerajinan dari ecobrick.

Tingkat pengetahuan peserta berdasarkan nilai dari pre-test dapat disimpulkan bahwa peserta belum begitu mengetahui mengenai ecobrick jika dilihat dari 6 pertanyaan pertanyaan pada nomor 3 sebanyak 27 orang menjawab tidak tahu dan 3 orang menjawab tahu dengan pertanyaan yaitu mengenai apakah bapak ibu sudah mengetahui cara pembuatan ecobrick?, banyak dari peserta menjawab belum mengetahui bagaimana cara pembuatan ecobrick itu sendiri. Sedangkan untuk pertanyaan ke empat para peserta menjawab tidak tahu dan yang sudah tahu seimbang yaitu sebanyak 15 orang menjawab tidak tahu dan 15 orang menjawab tahu (Gambar 4).

Pertanyaan keempat ini berbunyi dampak dari pencemaran sampah plastik bagi lingkungan. 15 dari para peserta sudah tahu dampak dari pencemaran sampah itu sendiri. Kegiatan yang berupa pelatihan merupakan suatu proses pembelajaran yang lebih menekankan pada praktek dari pada teori yang dilakukan seseorang atau kelompok agar mereka lebih terampil. Ini sesuai dengan pendapat Tanjung dalam Sukiarko (2007) mengemukakan bahwa pelatihan merupakan suatu proses belajar mengajar terhadap pengetahuan dan keterampilan tertentu serta sikap agar peserta semakin terampil dan mampu melaksanakan tanggung jawabnya dengan semakin baik, sesuai dengan standar. 


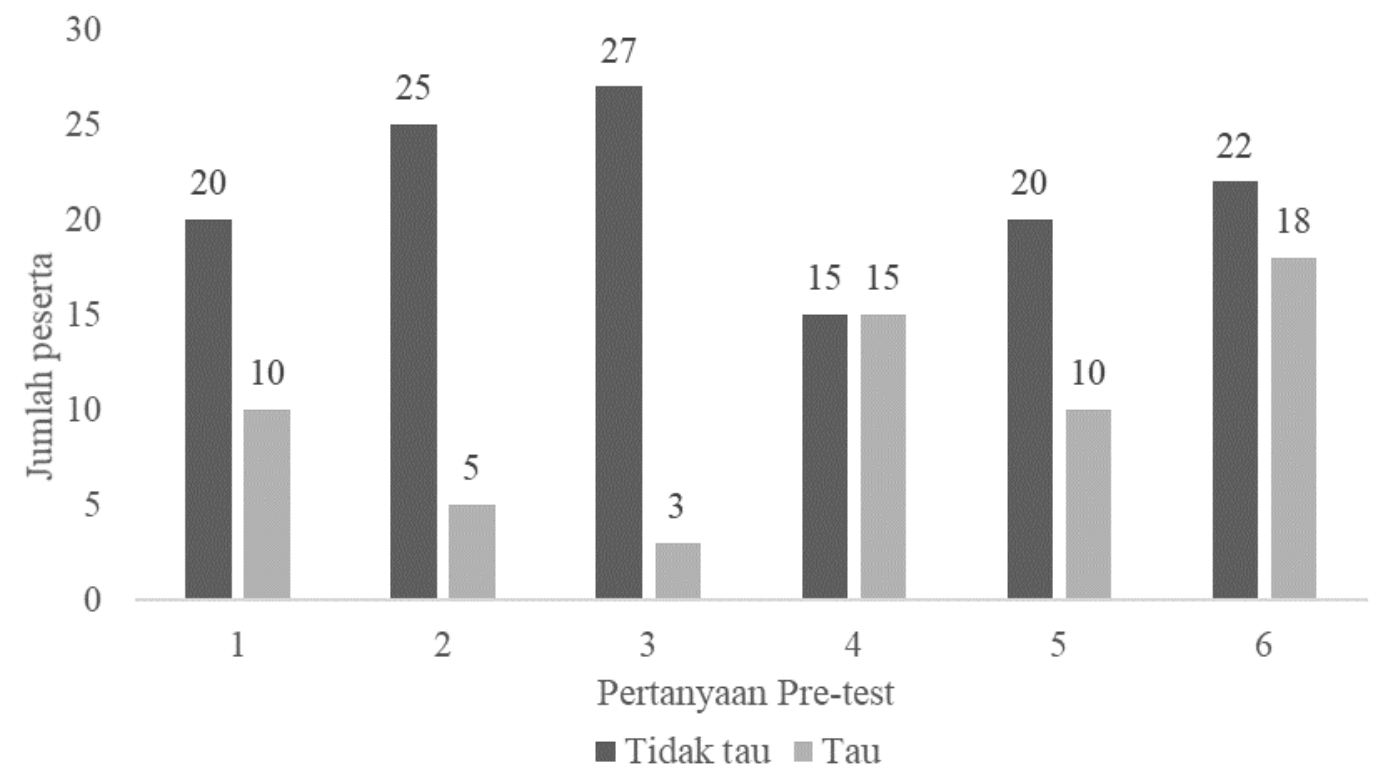

Gambar 4. Tingkat pengetahuan peserta sebelum dilakukan kegiatan pengabdian

Penyebab ketidaktahuan juga pengaruh kurangnya informasi mengenai ecobrick, pelatihan ini juga bertujuan untuk transfer informasi dan pengetahuan dari Tim Pengabdian kepada masyarakat. Pelatihan ini juga berguna untuk memperoleh dan meningkatkan keterampilan masyarakat dalam mengolah sampah.

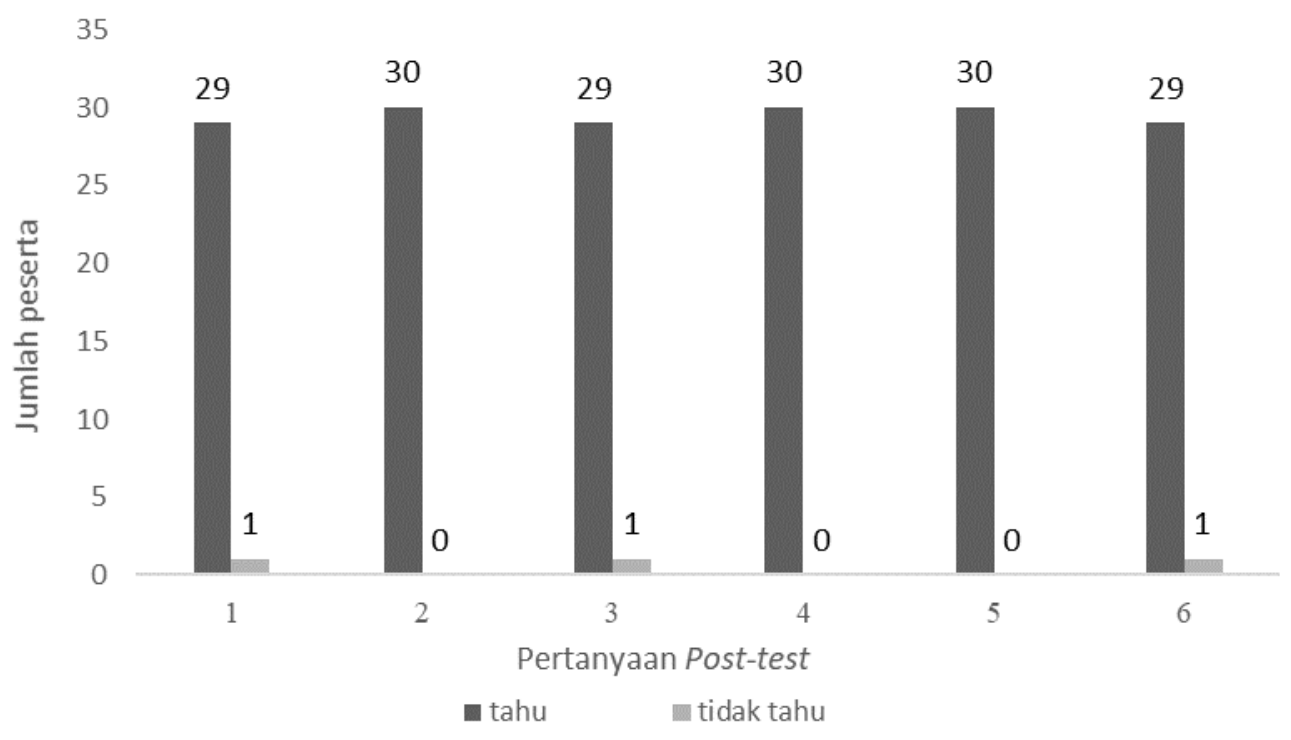

Gambar 5. Tingkat pengetahuan peserta setelah dilakukan kegiatan pengabdian

Pada Gambar 5 tingkat pengetahuan peserta meningkat dari yang tidak tahu menjadi tahu, ini membuktikan bahwa pelatihan ini memberikan pengaruh kepada tingkat pengetahuan mengenai ecobrick. Dari segi teori para peserta sudah memahami dengan baik. Metode ceramah menggunakan slide sangat bermanfaat karena ceramah dapat digunakan untuk pemberian penyuluhan pada sasaran dengan pendidikan rendah maupun tinggi. Pelaksaan metode ini perlu penguasaan sasaran dengan penyampaian dan gerak-gerik yang meyakinkan. 
Hasil ini juga sesuai dengan rerata nilai pre-test dan post-test jauh berbeda, yaitu 30,6 pada pre-test dan 80,5 pada post-test. Kisaran nilai ini menunjukkan bahwa sebelum mengikuti penyuluhan, masyarakat belum mempunyai bekal pengetahuan tentang ecobrick akan tetapi pengetahuan ini meningkat dengan adanya materi yang diberikan. Secara keseluruhan tingkat pengetahuan peserta meningkat dan para peserta bisa mengaplikasikan cara pembuatan ecobrick ini untuk membuat kerajinan dan juga bisa dijadikan peluang bisnis. Kegiatan harus dilakukan monitoring secara rutin agar masyarakat dapat menerapkan ecobrick dan lingkungan juga akan bersih.

Masyarakat Kampung Bunga Raya pada umumnya belum terlalu mengetahui pembuatan ecobrick, akan tetapi masyarakat sangat ingin mengaplikasikan ecobrick sebagai salah satu cara untuk mengurangi penumpukan sampah plastik. Karena pada dasarnya mereka belum mengetahui bagaimana cara mengolah sampah plastik dengan baik.

Sebaiknya perlu melakukan pelatihan mengenai pembuatan ecobrick yang lebih banyak, tidak hanya pembuatan kursi, meja tetapi juga jenis lainnya. Sehingga bisa memberikan peluang usaha baru dengan nilai jual yang tinggi dengan modal yang tidak besar. maka diperlukan adanya bimbingan rutin Tim Penyuluh dari Fakultas Perikanan dan Kelautan Universitas Riau bagi masyarakat Kampung Bunga Raya Kabupaten Siak. Agar masyarakat menjadi unggul dalam ekonomi dan lingkungan pun terjaga. Secara keseluruhan ketercapaian program pelatihan pembuatan ecobrick ini berhasil dengan tingkat ketercapaian sebesar $96 \%$, dilihat dari peserta pelatihan mengalami peningkatan pemahaman mengenai bahaya sampah plastik yang diukur melalui pre-test dan post-test yang diberikan sebelum dan setelah pemberian materi. Dan setelah kegiatan pengabdian ini selesai mereka sampai saat ini masih membuat kerajinan dari ecobrick.

\section{KESIMPULAN}

Dampak yang ditimbulkan dari pengelolaan sampah yang minim yaitu akan menyebabkan pencemaran pada air tanah, terganggunya rantai makanan, menyebabkan polusi udara, dan pencemaran tanah. Dalam menentukan permasalahan, tim telah melakukan koordinasi dengan mitra untuk mengetahui masalah dan potensi yang dimiliki sehingga mampu digunakan sebagai solusi dalam rangka ikut memecahkan permasalahan lingkungan di masyarakat. Permasalahan tersebut adalah menumpuknya sampah plastik, kurangnya kesadaran untuk mengelola sampah plastik, dan tidak adanya pemanfaatan sampah plastik. Oleh karena itu, saat ini berkembang metode pemanfaatan limbah plastik dengan menggunakan metode ecobrick. Pelaksanaan program pengabdian pengolahan sampah ini dimaksudkan agar masyarakat bisa memanfaatkan sampah untuk menghasilkan barang-barang yang bermanfaat. Selain menyenangkan, kegiatan pembuatan ecobrick juga memiliki manfaat yang beragam, terutama berkontribusi pada pengurangan sampah plastik serta diharapkan dapat merangsang banyak aspek seperti kreativitas dan seni masyarakat.

Ecobrick yang dibuat diperlukan kajian lebih dalam jika akan dipergunakan sebagai pengganti batu bata untuk dinding rumah, baik penentuan standar kepadatan, kekuatan dan kelenturannya. Pada sisi lain diperlukan inovasi agar mendapatkan kreasi-kreasi yang menarik dari susunan ecobrick yang telah dibangun. 


\section{UCAPAN TERIMA KASIH}

Kegiatan pengabdian kepada masyarakat ini merupakan pengabdian DIPA Universitas Riau yang didanai oleh Universitas Riau. Kami, tim pengabdian, mengucapkan terima kasih kepada Universitas Riau yang telah memberikan bantuan dana sehingga kegiatan ini bisa dilakukan. Kami juga mengucapkan terima kasih kepada seluruh pihak yang telah ikut serta dalam kegiatan pengabdian kepada masyarakat ini.

\section{Daftar Pustaka}

1. Adianti, I., \& Ayuningtyas, N.V. (2020). Pelatihan Pembuatan Ecobrick kepada Anak-Anak Siswa SD Kanisisus Kembaran, Bantul, Yogyakarta. Jurnal Ilmiah Padma Sri Kreshna. 2(1): 1-8. https://doi.org/10.37631/psk.v2i1.121

2. Andriastuti, B.T., Arifin, \& Laila, F. (2019). Potensi Ecobrick Dalam Mengurangi Sampah Plastik Rumah Tangga di Kecamatan Pontianak Barat. Jurnal Teknologi Lingkungan Lahan Basah, 7(2): 055-063. https://doi.org/10.26418/jtllb.v7i2.36141

3. Asih, H.M., \& Fitriani, S. (2018). Penyusunan Standard Operating Procedure (SOP) Produksi Inovasi Ecobrick. Jurnal Ilmiah Teknik Industri, 17(2), 144. https://doi.org/10.23917/jiti.v17i2.6832

4. Claessens, M., Meester, S.D., Landuyt, L.V., Clerck, K.D., \& Janssen, C.R. (2011). Occurrence and distribution of microplastics in marine sediments along the Belgian coast. Marine Pollution Bulletin, 62(10), 2199-2204. https://doi.org/10.1016/j.marpolbul.2011.06.030

5. Fauzi, M., Sumiarsih, E., Adriman, Rusliadi, Hasibuan, I.F., Fista, A., \& Hermawita, A. (2019). Ecobrick Solusi Sampah Plastik Masa Kini. UR Press.

6. Hohenblum, P., Liebmann, B., \& Liedermann, M. (2015). Plastic and Microplastic in the Environment. Umweltbundesamt $\mathrm{GmbH}$.

7. Lusher, A.L., McHugh, M., \& Thompson, R.C. (2013). Occurrence of microplastics in the gastrointestinal tract of pelagic and demersal fish from the English Channel. Marine Pollution Bulletin, 67(1-2), 94-99. https://doi.org/10.1016/j.marpolbul.2012.11.028

8. Moore, C.J., Lattin, G.L., \& Zeller, A.F. (2004). Density of Plastic Particles found in zooplankton trawls from Coastal Waters of California to the North Pacific Central Gyre. Algalita Marine Research Foundation.

9. Mujiarto, I. (2005). Sifat dan karakteristik material plastik dan bahan aditif. Traksi, 3(2):1-9.

10. Sirait, M. (2009). Sulap Sampah Plastik Lunak Jadi Jutaan Rupiah. B-First.

11. Sukiarko, E. (2007). Pengaruh Pelatihan dengan Metode Belajar Berdasarkan Masalah terhadap Pengetahuan dan Keterampilan Kader Gizi dalam Kegiatan Posyandu [Unpublished Master Thesis]. Universitas Diponegoro.

12. Suminto, S. (2017). Ecobrick: solusi cerdas dan kreatif untuk mengatasi sampah plastik. PRODUCTUM Jurnal Desain Produk (Pengetahuan Dan Perancangan Produk), 3(1), 26. https://doi.org/10.24821/productum.v3i1.1735

13. Thompson, R.C., Olsen, Y., Mitchell, R.P., Davis, A., Rowland, S.J., John, A.W.G., McGonigle, D. and Russell, A.E. (2004) Lost at sea: Where is all the plastic?. Science, 304(5672), 838-838. https://doi.org/10.1126/science.1094559

14. Thompson, R.C., Swan, S.H., Moore, C.J., \& vom Saal, F.S. (2009). Our plastic age. Philosophical Transactions of the Royal Society B: Biological Sciences, 364(1526): 19731976. https://doi.org/10.1098/rstb.2009.0054 